\title{
A simple turnover technique to harvest skin graft from the avulsed skin
}

\author{
Ravikiran Naalla, ${ }^{1}$ Maneesh Singhal ${ }^{2}$
}

'Department of Plastic and Reconstructive Surgery, All India Institute of Medical Sciences, New Delhi, India

${ }^{2}$ Department of Plastic Reconstructive and Burns Surgery, All India Institute of Medical sciences, New Delhi, Delhi, India

\section{Correspondence to} Professor Maneesh Singhal, drmaneesh@gmail.com

Accepted 3 October 2017
CrossMark

$$
\begin{aligned}
& \text { To cite: Naalla R, Singhal M. } \\
& \text { BMJ Case Rep Published } \\
& \text { Online First: [please } \\
& \text { include Day Month Year]. } \\
& \text { doi:10.1136/bcr-2017- } \\
& 222784
\end{aligned}
$$

\section{DESCRIPTION}

Skin avulsion injuries are one of the most common soft tissue injuries encountered by the trauma surgeons and reconstructive surgeons. Harvesting skin graft from the avulsed skin either avoids or reduces the requirement of subsequent skin grafting.

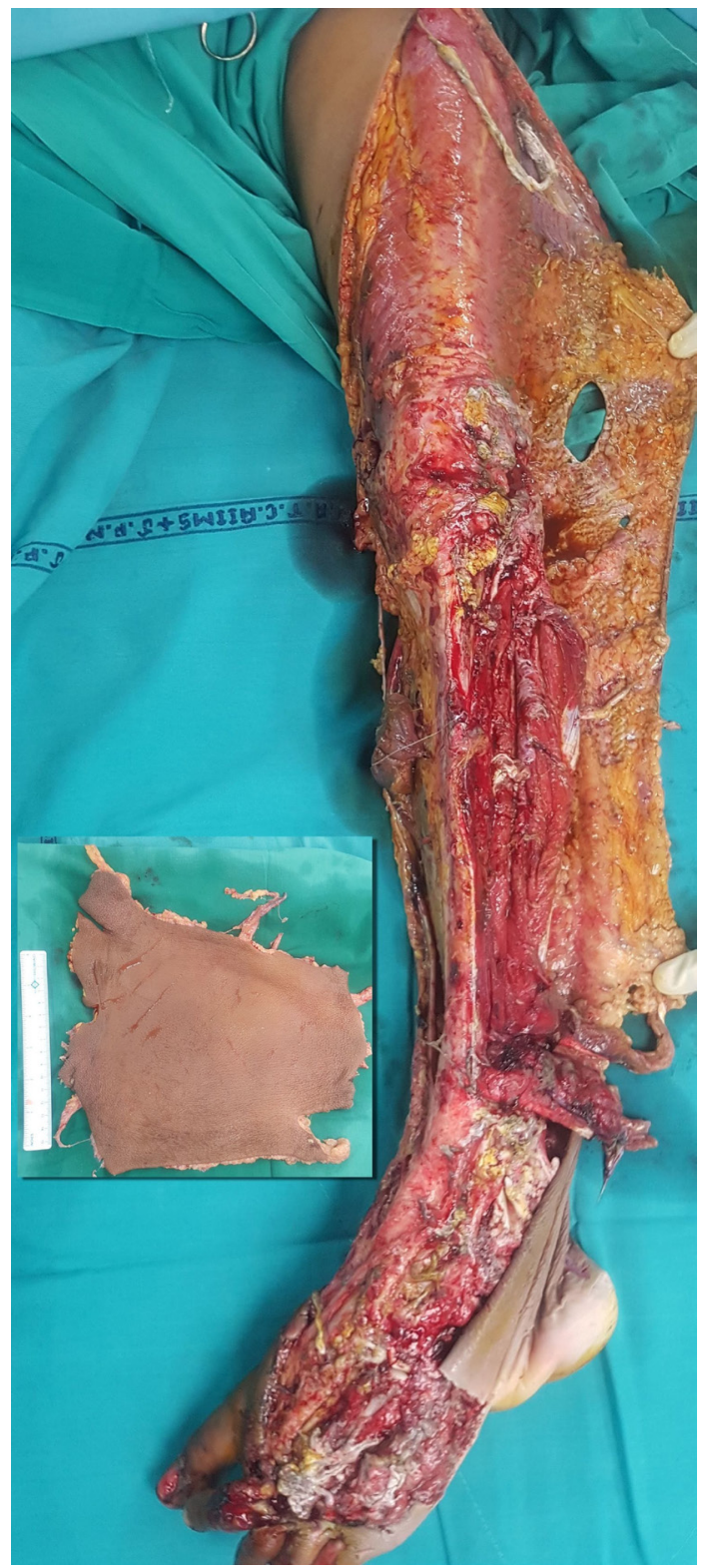

Figure 1 Image showing extensive avulsion injury of left lower limb extending from thigh to the foot. The image in the inset shows one of the two large pieces of degloved skin before harvesting skin graft.

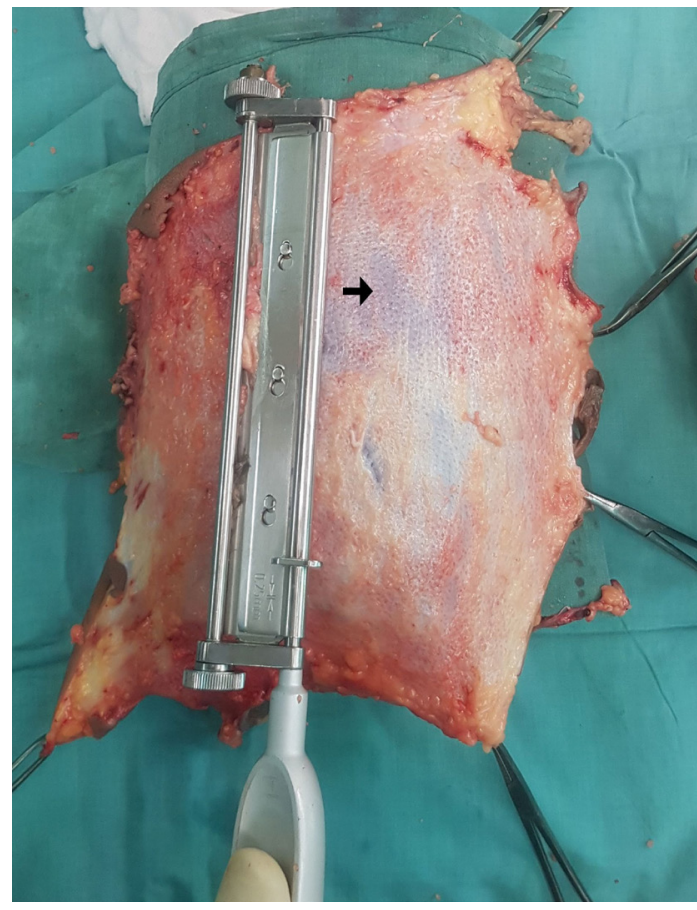

Figure 2 Image showing the technique of dermis excision from the defatted avulsed skin. The arrow indicates an area of split thickness skin graft.

A 12-year-old child presented to us with an avulsion injury left lower limb 6 hours following road traffic accident. On examination, the patient had avulsion of skin from the anterolateral surface of the thigh and circumferential skin avulsion extending from knee joint to the foot (figure 1). The non-viable avulsed skin was debrided till the fresh bleeding edges were obtained. The avulsed skin was cleaned, and gross defatting was performed with a surgical blade and curved Metzenbaum scissors in a turnover fashion (dermal side facing above and epidermis side facing below). Once the thick layer of fat was removed from the avulsed skin, it was placed over a rolled sheet so that the skin can be stretched with multiple artery forceps (figure 2). The retained fatty later after gross defatting is excised with a Humby skin graft knife (figure 2). In our patient, a thin layer of dermis was also removed so that thick split thickness graft was obtained. Dermis component may not be removed if a full thickness graft harvest is intended. The harvested graft was placed over the thigh and leg in the same setting. In the second stage, leftover areas were covered and split thickness skin grafts were harvested from opposite thigh. The initial skin graft take was around 90\% when evaluated at 2 weeks (figure 3); however, on the follow-up visit 


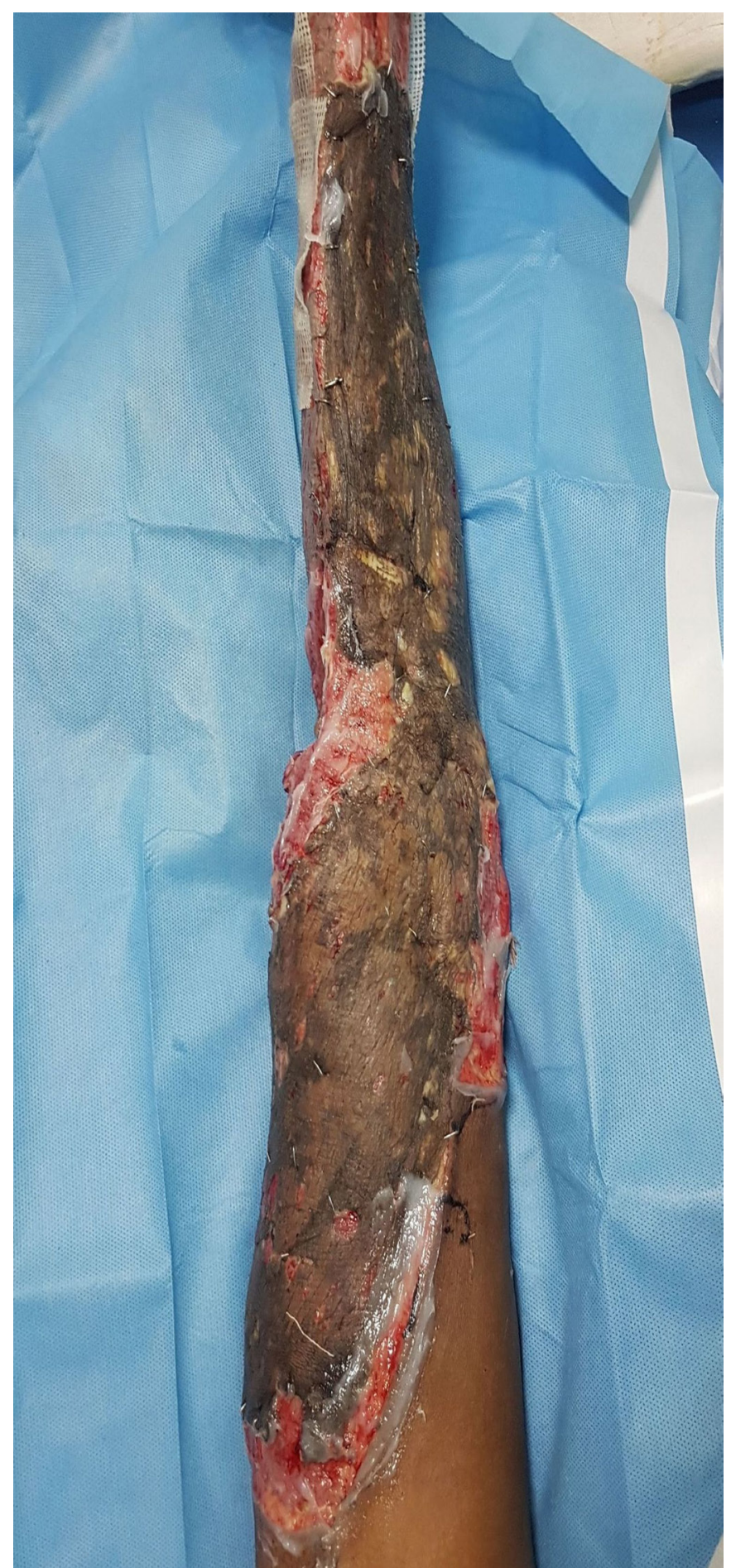

Figure 3 Image showing well-settled skin graft.

at the fourth week, we noted partial graft loss due to pseudomonas infection (figure 4). Skin graft loss following pseudomonas infection is not uncommon. ${ }^{1} \mathrm{He}$ underwent further debridement and skin grafting in due course. Patient required less skin graft harvest as much as that of the wound was managed initially with skin graft from the avulsed skin.

Several authors had reported their techniques of skin harvest from the degloved skin. ${ }^{23}$ The methods described in the literature are based on harvesting skin graft from the skin surface upside. With these techniques, multiple sheets of split thickness skin grafts can be harvested. With our turnover technique of defatting and dermis
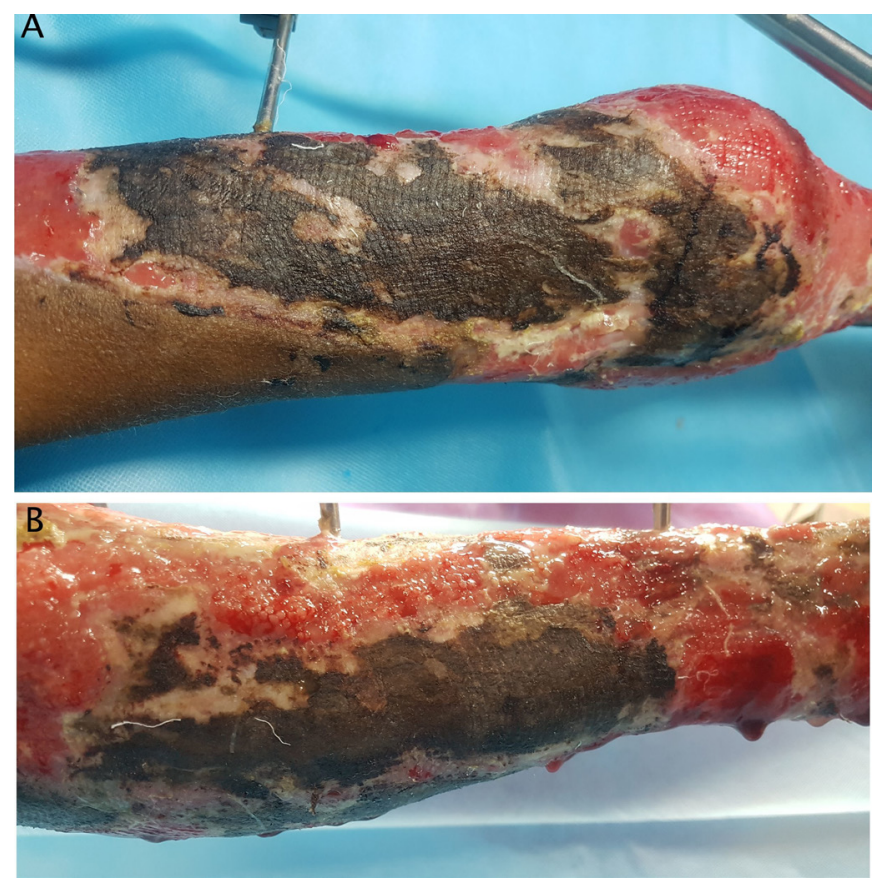

Figure 4 Image showing partial graft loss in the follow-up period.

Learning points

- Harvesting skin graft from the avulsed skin either avoids or reduces the requirement of subsequent skin grafting.

- Using the turnover technique of defatting and dermis excision with Humby knife from the dermal side of the skin, either full thickness graft of split thickness skin graft can be harvested in a single large sheet of skin.

- The large sheet of skin is easy to anchor to the raw area and promotes earlier wound healing with less number of wound dressings.

excision with Humby knife from the dermal side of the skin, either full thickness graft of split thickness skin graft can be harvested in a single large sheet of skin. The large sheet of skin is easy to anchor to the raw area and promotes earlier wound healing with less number of wound dressings. We prefer to harvest split thickness skin graft to full thickness graft to avoid cumbersome bolster dressings in large wounds. The proposed technique is easy to learn and to execute even in limited resource settings.

Contributors RN was involved in manuscript preparation. MS was involved in editing and processing of the manuscript.

Competing interests None declared.

Patient consent Parental consent obtained.

Provenance and peer review Not commissioned; externally peer reviewed.

(c) BMJ Publishing Group Ltd (unless otherwise stated in the text of the article) 2017. All rights reserved. No commercial use is permitted unless otherwise expressly granted.

\section{REFERENCES}

1 Unal S, Ersoz G, Demirkan F, et al. Analysis of skin-graft loss due to infection: infectionrelated graft loss. Ann Plast Surg 2005;55:102-6.

2 Dickson JK, Mills C, Devaraj V. Surgical tip: simple technique for harvesting split thickness skin grafts from degloved skin. J Plast Reconstr Aesthet Surg 2010;63:e233.

3 Koul A, Patil RK. A simple method of harvesting skin graft from avulsed and detached skin. J Plast Reconstr Aesthet Surg 2008;61:1131-2. 
Copyright 2017 BMJ Publishing Group. All rights reserved. For permission to reuse any of this content visit http://group.bmj.com/group/rights-licensing/permissions.

BMJ Case Report Fellows may re-use this article for personal use and teaching without any further permission.

Become a Fellow of BMJ Case Reports today and you can:

- Submit as many cases as you like

- Enjoy fast sympathetic peer review and rapid publication of accepted articles

Access all the published articles

Re-use any of the published material for personal use and teaching without further permission

For information on Institutional Fellowships contact consortiasales@bmjgroup.com

Visit casereports.bmj.com for more articles like this and to become a Fellow 